DOI https://doi.org/10.30525/978-9934-588-80-8-1.14

\title{
THE EMPIRICAL CORRELATES FOR DISABLED STUDENTS' SELF-REALIZATION
}

\author{
Kuprieieva O. I. \\ Candidate of Psychological Sciences, Associate Professor, \\ Doctoral Student \\ Taras Shevchenko National University of Kyiv \\ Kyiv, Ukraine
}

Scientists' increased attention to the problem of self-realization is caused by many reasons, in particular, the decisive role of self-realization in human development; the increased requirements for human capacities in selfdevelopment and self-improvement; a human need in conscious independent intervention into one's self-development, self-actualization.

The personal self-realization becomes especially important for disabled students, for whom general education and professional training is an effective means for being in demand by society, economic independence and mobility, freedom of choice, achievement of life goals and personal selfrealization.

Many researchers, in particular, working within the humanistic and positive approaches, focus on an individual's functioning in adverse developmental conditions (which include disabilities) and identify resourceful personal traits, i.e. contributing to self-realization, helping overcome various difficulties and achieve psychological well-being $[1 ; 3 ; 4]$.

Self-realization as a process of an individual's actualization and realization in the world, his/her inner positive, creative desire for development, psychological maturity and competence, involves, first of all, active personal efforts, self-knowledge of his/her abilities, values, goals, self-image, own capabilities and resources, translating them from the potential state (opportunities) to the actual (the reality) one, implementing then in real life conditions [2]. Thus, it is important to study the psychological foundations of an individual's self-realization, to identify factors stimulating an individual's innate potential (abilities, capabilities) and promoting self-realization, actualizing the individual's activities, his/her ability to choose independently the vector of self-realization.

The empirical study involved 206 disabled students studying at Kyiv universities. Their age was 19-22 years. The following methods were used: E. Shostrom Personal Orientation Inventory (adapted by A. Lazukin, 
N. Kalina); Purpose-in-Life Test (Crumbaugh J.,\& Maholick L, adapted by D.O. Leontiev); Maddi Hardiness Scale (adapted by D.O. Leontiev, O.I. Rasskazova); World Assumptions Scale of R. Janoff-Bulman (adapted by O.A. Kravtsova); Zimbardo Time Perspective Inventory (adapted by G. Syrtsova, O.T. Sokolova, O.V. Mitina); the Self-Attitude Questionnaire of V.V. Stolin, S.R. Pantileev; Life Style Index (R. Plutchik, H.Kellerman); the questionnaire of coping strategies proposed by R. Lazarus, S. Folkman (adapted by T. Kryukova). The obtained data were processed with software SPSS Statistics 21.0.

We identified three groups of students according to the key parameter of «self-actualization» from Shostrom Personal Orientation Inventory: with high self-actualization ( $\mathrm{n}=53,25.7 \%$ of the sample), with average selfactualization ( $\mathrm{n}=103,50 \%$ of the sample) and with low self-actualization $(\mathrm{n}=50,24,2 \%$ of the sample). For further research, we combined the groups of students with average and high self-actualization.

With the factor analysis, we identified six factors of qualities ensuring disabled students' self-realization; their contribution to the total data dispersion was $88.3 \%$.

Table 1

Factors of disabled students' self-realization $(n=153)$

\begin{tabular}{|c|l|}
\hline Factor load & \multicolumn{1}{|c|}{ Parameters forming the factor } \\
\hline & $\begin{array}{l}\text { Self-confidence }(0.96), \text { global self-attitude }(0.93), \text { self- } \\
\text { blame }(-0.89), \text { self-esteem }(0.89), \text { self-understanding } \\
(0.87), \text { self-sympathy }(0.87), \text { result }- \text { life }(0.84), \text { life goals } \\
(0.77), \text { regression }(-0.76), \text { locus of control - life }(0.75), \\
\text { the need for knowledge }(0.72), \text { psychological hardiness } \\
(0.70), \text { control }(0.67), \text { self-acceptance }(0.67), \text { expected } \\
\text { attitude from others }(0.66) .\end{array}$ \\
\hline \multirow{3}{*}{$16,8 \%$} & $\begin{array}{l}\text { value of Self }(-0.83), \text { self-interest }(0.80), \text { projection } \\
(0.78), \text { expected attitude from others }(0.77), \\
\text { commitment }(-0.70) . .\end{array}$ \\
\hline $13,8 \%$ & $\begin{array}{l}\text { self-consistency }(0.84), \text { fatalistic future }(-0.84), \\
\text { self-understanding }(0.62) . .\end{array}$ \\
\hline $10,0 \%$ & $\begin{array}{l}\text { benevolence of world and people }(-0.91), \\
\text { autonomy }(0.79), \text { self-control }(0.77)\end{array}$ \\
\hline $7,3 \%$ & $\begin{array}{l}\text { hedonistic present }(0.65), \text { commitment }(0.55), \text { challenge } \\
(0.54), \text { need for knowledge }(0.52), \text { sociability }(0.51 .\end{array}$ \\
\hline $6,7 \%$ & positive past $(0.87)$, justice of the world $(0.64)$ \\
\hline
\end{tabular}

This factor description explains fully the origins of the studied students' self-realization. They determine the students' motivational focus on self- 
realization, self-expression, self-acceptance, values of one's own Self, life goal achievement, expansion of one's own experience, knowledge, positive relationships with others, competence in the time perspective of one's own life.

The next step in our study was to identify the most essential independent variables predicting the disabled students' self-realization.

Table 2

Prognostic models of disabled students' self-realization $(n=153)$

\begin{tabular}{|c|c|c|c|c|}
\hline Model & $\mathbf{R}$ & R Square & $\begin{array}{c}\text { Adjusted R } \\
\text { Square }\end{array}$ & $\begin{array}{c}\text { Std. Error } \\
\text { of the Estimate }\end{array}$ \\
\hline 1 &, $639^{\mathrm{a}}$ &, 408 &, 397 & 4,102 \\
\hline 2 &, $747^{\mathrm{b}}$ &, 558 &, 541 & 3,578 \\
\hline 3 &, $839^{\mathrm{c}}$ &, 704 &, 687 & 2,956 \\
\hline 4 &, $859^{\mathrm{d}}$ &, 739 &, 718 & 2,804 \\
\hline 5 &, $879^{\mathrm{e}}$ &, 772 &, 749 & 2,645 \\
\hline
\end{tabular}

${ }^{a}$ Predictors: (constant), commitment

${ }^{b}$ Predictors: (constant), commitment, locus of control - Self

${ }^{\mathrm{c}}$ Predictors: (constant), commitment, locus of control - Self, values

d Predictors: (constant), commitment, locus of control - Self, values, rationalization

e Predictors: (constant), commitment, locus of control - Self, values, rationalization, hypercompensation

f dependent variable: self-realization

Five models can predict the disabled students' self-realization. Thus, using regression analysis, we found that the fifth model predicts most accurately self-realization of the students with high self-actualization; this model included the following predictors: commitment, locus of control Self, values, rationalization, hypercompensation, which explains $77 \%$ of the variance. Locus of control - Self (Beta indicator was the highest) had the greatest influence on self-realization.

Thus, it is really important for self-realization to be confident in the power of own Self, look at oneself as a strong personality who is able to build life in accordance with their own goals, meaningfully and control its events; to give preference to the values of self-actualization and have the desire for a harmonious existence and effective interactions with others.

\section{References:}

1. Csikszentmihalyi M. The promise of positive psychology. Psychological Topics. 2009. 18 (2). P. 203-211. 
2. Olga Kuprieieva. Psychological Characteristics of Self-realization of Students with Disabilities. Social Welfare: Interdisciplinary Approach. 2015. Vol. 2 No 5. P. 64-74. http://socialwelfare.eu/index.php/sw/article/view/228

3. Ryan R. M. Self-determination theory: Basic Psychological Needs in Motivation Development and Wellness. New York, NY: Guilford Press. 2017. $756 \mathrm{p}$.

4. Seligman M. E., Scikszentmihalyi M. Positive psychology. An introduction. American Psychologist. 2000. Vol. 55 (1). P. 5-14. https://doi.org/10.1037/0003-066X.55.1.5

DOI https://doi.org/10.30525/978-9934-588-80-8-1.15

\title{
ГЕНДЕРНІ ОСОБЛИВОСТІ МІЖОСОБИСТІСНИХ ВІДНОСИН КАР'СРНО-УСПІШНИХ ЖІНОК
}

\author{
Літвінова О. В. \\ кандидат психологічних наук, \\ дочент кафедри психології, педагогіки та філософії \\ Кременчуцький начіональний університет \\ імені Михайла Остроградського
}

Герасимова А. Б.

здобувач другого (магістерського) рівня спеціальності «Психологія»

Кременчуцький національний університет

імені Михайла Остроградського

м. Кременчук, Полтавська область, Украӥна

Метою роботи $\epsilon$ аналіз емпіричних студій щодо гендерних особливостей міжособистісних відносин жінок, які $є$ успішними в кар'єрі. У сучасних умовах якісно новим образом постає проблема розвитку і використання людського потенціалу, пред’являються більш високі вимоги до самостійності, ініціативності, підприємливості людини, що викликані змінами в суспільстві. Кар'єра являє собою безперервний процес успішного просування по сходах адміністративної, соціальної, професійної, майнової та іншої ієрархії з метою досягнення бажаного статусу і відповідного йому рівня і якості життя. У суспільній свідомості кар'єрне просування і управління в більшій мірі пов'язане 3 представниками чоловічої статі. Разом 3 тим, посилення жіночої емансипації призводить до того, що багато жінок хочуть бути 